\title{
Health Risks Associated with Heavy Metals in Fine Particulate Matter: A Case Study in Delhi City, India
}

\author{
Isha Khanna1, Mukesh Khare1, Prashant Gargava² \\ ${ }^{1}$ Department of Civil Engineering, Indian Institute of Technology, Delhi, India \\ ${ }^{2}$ Department Central Pollution Control Board, Delhi, India \\ Email: isha.khanna1@gmail.com
}

Received February 2015

\section{Abstract}

The concentrations of twenty five heavy metals adsorbed to fine fraction of particulate matter, $\mathbf{P M}_{2.5}(\mathrm{~d} \leq 2.5 \mu \mathrm{m})$ have been experimentally analysed at a sampling site located at the kerbside along a National Highway in Delhi city, India. The sampling has been carried out for 12-hour using Ecotech Intruments, APM550. The PM $_{2.5}$ has been collected on PTFE filter papers for the winter season. Later, the filter papers have been analysed for various heavy metal concentrations using ED-XRF. It has been observed that the metals concentrations are in this trend: $\mathrm{Si}>\mathrm{K}>\mathrm{S}>\mathrm{Ca}=\mathrm{Fe}>$ $\mathrm{Zn}=\mathrm{Pb}>\mathrm{Br}$. it is observed that $\mathrm{Si}$ has high co-relation with $\mathrm{Ca}, \mathrm{Fe}$ and $\mathrm{K}$, which may be due to crustal origin of all three elements; while $\mathrm{S}, \mathrm{Br}$ and $\mathrm{Pb}$ may be from vehicular exhaust emissions and/or abrasions due to brake and tyre wear. The potential health risks associated with different carcinogenic heavy metals have also been calculated. One of the health risk indicators, the excess cancer risk (ECR), is found to be in the order as $\mathrm{As}>\mathrm{Cd}>\mathrm{Pb}>\mathrm{Cr}>\mathrm{Ni}$.

\section{Keywords}

Fine PM, Heavy Metals, Excess Cancer Risk, Kerbside, National Highway

\section{Introduction}

Air quality has been a cause of concern all over the world because concentrations of various criteria pollutants frequently violate the ambient standards, particularly in developing countries. Particulate matter (PM), one of the six criteria pollutants, comprises a complex mixture of different elements and compounds. $\mathrm{PM}_{2.5}$ (diameter < $2.5 \mu \mathrm{m})$ can penetrate into the lungs more readily and are therefore more likely to have short- and long-term effects such as decreased lung functions and alterations in lung tissues, premature death and increased respiratory symptoms and disease [1]. Fine PM $\left(\mathrm{PM}_{2.5}\right)$ typically contains wide range of chemical species, ranging from metals to organic and inorganic compounds [2]. Among inorganic compounds, most important ones are the trace metals, which are emitted by various sources such as road dust, geogenic materials, motor vehicles, coal and oil combustion, construction activities, incineration and other industrial activities [3] [4]. 
Delhi, the capital city of India with over 14 million populations is experiencing health risks from various such pollutants, especially the respirable particulate matters. There are many different sources of PM like road side dust, vehicles, industries, trans-boundary migrations, power plants, solid waste and local sources. Particulate matters from these sources may contain hazardous pollutants and can have carcinogenic and mutagenic effects. Thus, identification of the sources and estimating their contributions to the ambient environment seem to be a paramount task for air quality management [5]. The study in 2010 has indicated that 223,000 deaths from lung cancer worldwide resulted from air pollution [6]. International Agency for Research on Cancer (IARC), specialized cancer agency of the World Health Organization classified outdoor air pollution as Group 1 carcinogenic to humans in October 2013 [7]. Against this background, a study has been carried out to determine the atmospheric concentrations of heavy metals in $\mathrm{PM}_{2.5}$ and their associated health risks (excess cancer risks) at one of the sampling sites located at the kerbside along a National highway in the Delhi city, India.

\section{Methodology}

\subsection{Sample Collection}

Delhi, the Capital of India is situated between latitudes $28^{\circ} 24^{\prime} 17^{\prime \prime}$ and $28^{\circ} 53^{\prime} 00 \mathrm{~N}$ and longitudes $76^{\circ} 50^{\prime} 24^{\prime \prime}$ and $77^{\circ} 20^{\prime} 37 " \mathrm{E}$ at 216 meters above the mean sea level (MSL). It is spread over an area of approximately $1500 \mathrm{sq}$. $\mathrm{km}$. The site on NH-2, a "kerbside", is in proximity of one of the busiest traffic intersections (Ashram Chowk) in Delhi. It is surrounded by ring roads connecting to Sarai Kale Khan, Mathura road, Lajpat nagar and Nizamuddin area, in different directions with a flyover on outer ring road (Sarai Kale Khan-Lajpat Nagar). The junction connects two States, namely UP (through Noida Toll Bridge) and Haryana (through Mathura road leading to Faridabad and to Gurgaon via Dhaula Kuan). Nizamuddin railway station and Sarai Kale Khan bus stand are about $2 \mathrm{~km}$ away from the Ashram Chowk. Overall, the study zone can be defined as high activity zone with very high traffic activity throughout day and night. There are several small scale industries, Okhla Industrial Area, a waste management plant and slumps nearby.

Sampling has been conducted for 24-hour duration for a sampling cycle of 12 - 12 hrs (i.e., morning sampling 8 am to $8 \mathrm{pm}$ and night $8 \mathrm{pm}$ to $8 \mathrm{am}$ ) using $\mathrm{PM}_{2.5}$ Sampler (Ecotech Instruments Pvt. Ltd., APM 550) which works on WINS impactor and runs at a constant flow rate of 16.67 L/min during December 2013-January 2014 for alternate weeks. The sampling details and average flow rate have been recorded and carefully maintained throughout the study. Field blank samples are collected by mounting blank filters onto the sampler for about 10 min without pumping any air. The polytetrafluoroethylene (PTFE) filters are pre-conditioned for 2 days in a controlled room (temperature: $20^{\circ} \mathrm{C} \pm 1{ }^{\circ} \mathrm{C}$, relative humidity: $50 \% \pm 5 \%$ ) before and after the sampling and then weighed using an analytical balance (Sartorius, CPA2PF). After sampling, the sampled filters are sealed in aluminum foil bags and stored in a freezer $\left(-20^{\circ} \mathrm{C}\right)$ prior to analysis.

\subsection{Chemical Analysis}

Elemental compositions of the TSP samples have been determined by Energy Dispersive X-Ray Fluorescence (ED-XRF) spectrometry (Epsilon 5 ED-XRF, PANalytical B. V.). The X-ray source is a side window X-ray tube with a gadolinium anode and operated at an accelerating voltage of $25-100 \mathrm{kV}$ and a current of $0.5-24 \mathrm{~mA}$ (maximum power: $600 \mathrm{~W}$ ). The characteristic X-ray radiation is detected by a germanium detector (PAN 32). Each sample is analyzed for 30 min to obtain a spectrum of X-ray counts versus photon energy with the individual peak energies matching specific elements and peak areas corresponding to elemental concentrations. In this study, 25 elements (i.e., Si, P, S, K, Ca, Ti, V, Cr, Mn, Fe, Co, Ni, Cu, Zn, As, Br, Rb, Sr, Y, Cd, In, Sn, Sb, $\mathrm{Ba}, \mathrm{Pb}$ ) have been determined. Blank correction is performed for QA/QC purposes.

\subsection{Excess Cancer Risk Assessment}

Excess cancer risks (ECRs) have been calculated using the unit risk and the PM-bound concentration of the metals which represents the total ambient concentration of the metals. ECRs can be calculated simply by using the following formula [8]-[10]:

$$
\mathrm{ECR}=\mathrm{CA} \times \text { IUR }
$$

where CA is the concentration of the pollutant $\left(\mu \mathrm{g} / \mathrm{m}^{3}\right)$ and IUR is the inhalation unit risk $\left(\mu \mathrm{g} / \mathrm{m}^{3}\right)^{-1}$. The infor- 
mation on the carcinogenic types and the unit risks of the metals is obtained from the US EPA database for IRIS (Integrated Risk Information System) [11].

\section{Results and Discussions}

\section{1. $\mathrm{PM}_{2.5}$ Concentrations}

The daily mean $\mathrm{PM}_{2.5}$ concentration at the sampling site has been observed to be $286.23( \pm 41.1) \mu \mathrm{g} / \mathrm{m}^{3}$. Observed concentrations are three to four times higher as compared to the air quality standard for $\mathrm{PM}_{2.5}$ of 60 $\mu \mathrm{g} / \mathrm{m}^{3}$ [12] and $35 \mu \mathrm{g} / \mathrm{m}^{3}$ [13]. This is because the selected sampling site is stop-and-go site at a national highway which has high traffic volume of approximately 170,000 vehicles per day [14].

Concentrations were found to be higher during night time as compared to daytime (Figure 1). This can be attributed to the movement of inter-state diesel-fueled heavy duty vehicles whose entry is allowed in the city from the national highway during the nighttime (after $8 \mathrm{pm}$ ). Also, due to the inversion conditions that prevail during the night in winters, fine PM particles remain suspended in the atmosphere for a very long time. During weekends, the concentrations of $\mathrm{PM}_{2.5}$ are again increasing when compared to weekdays. It may be due to additional weekend trips.

\subsection{Heavy Metals Concentrations}

$\mathrm{Si}$, being the crustal element, is found to be maximum i.e. 33\%, followed by $\mathrm{K}, 21 \%$ and S, 20\%. The concentration trend shows $\mathrm{Si}>\mathrm{K}>\mathrm{S}>\mathrm{Ca}=\mathrm{Fe}>\mathrm{Zn}=\mathrm{Pb}>\mathrm{Br}$ (Figure 2). However, it is observed that $\mathrm{Si}$ has high co-relation with $\mathrm{Ca}$, $\mathrm{Fe}$ and $\mathrm{K}$, which may be due to crustal origin of all three elements; while $\mathrm{S}, \mathrm{Br}$ and $\mathrm{Pb}$ may be from vehicular exhaust emissions and/or abrasions due to brake and tyre wear.

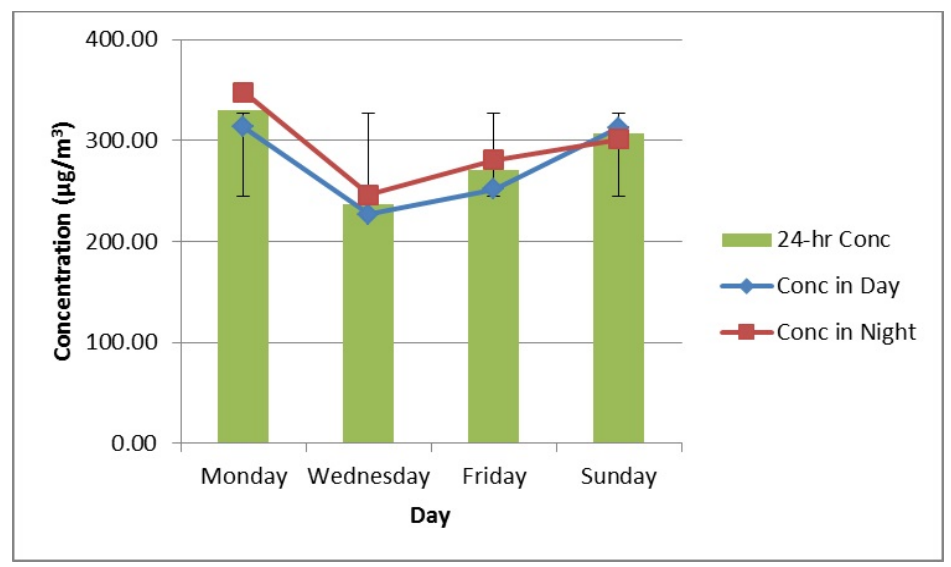

Figure 1. Diurnal variations in $\mathrm{PM}_{2.5}$ concentrations at the sampling site.

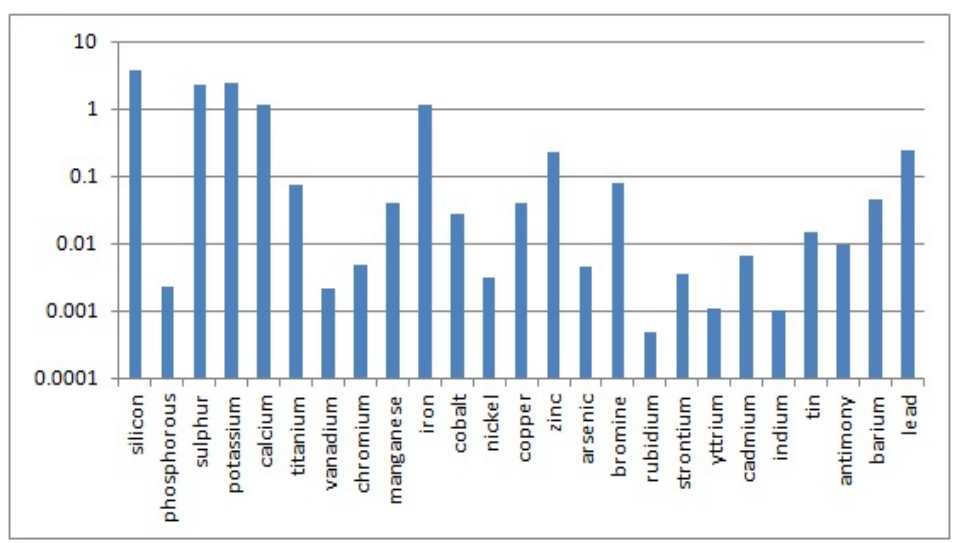

Figure 2. Metals concentrations in ambient $\mathrm{PM}_{2.5}$ samples. 
The high concentrations of Zn may have its origin from automotive sources i.e. lubricating oil, wear and tear of vulcanized rubber tyres and corrosion of galvanized vehicular parts but it is considered to be a good marker for tyre wear [15] [16]. Although direct emissions of $\mathrm{Pb}$ from vehicular exhausts ceased as leaded gasoline was banned in Delhi but lead is still persistent in dust from earlier emissions because of its long residence time in theenvironment [17]. Copper is observed to be coming from brake wear, tyre wear and wheel bearing [18]. Copper can be attributed to solid waste dumping and incineration also [19]. Apart from road dust Mn is mostly emitted by automobile exhaust [20] [21]. It is used as an additive in unleaded gasoline and Manganese tricarbonyl compound in unleaded petrol is used to enhance automobile performance but they have toxicological significance [22].

\subsection{Excess Cancer Risk Assessment}

The elements of As, $\mathrm{Cd}, \mathrm{Cr}, \mathrm{Ni}$ and $\mathrm{Pb}$ are the known carcinogenic metals among the twenty-five metals investigated in this study and are introduced by exposure through the inhalation pathway. The IARC [23] [24] has classified $\mathrm{Cd}$ and $\mathrm{Ni}$ are classified as Class 1 carcinogenic elements and $\mathrm{Pb}$ as Class 2B carcinogenic element. The chromium identified in this study included $\mathrm{Cr}$ (III), however, it is known that the concentration ratio of carcinogenic $\mathrm{Cr}$ (VI) to non-carcinogenic $\mathrm{Cr}(\mathrm{III})$ in ambient air is about 1:6. Therefore, the concentration of $\mathrm{Cr}$ (VI) used for the carcinogenic risk assessment was calculated as one seventh of the total concentration [9] [10] [25]. There are different forms of nickel including nickel refinery dust, nickel subsulfide $\left(\mathrm{Ni}_{3} \mathrm{~S}_{2}\right)$, nickel carbonyl and nickel-soluble salts (nickel chloride, nickel sulfate). The US EPA has classified nickel refinery dust and nickel subsulfide as group A materials, known human carcinogens. Lead is classified as Group B2, but human evidence is inadequate in IRIS thus, values for IUR were selected from California Environmental Protection Agency.

Table 1 shows the estimated ECR of PM-bound carcinogenic elements for the average values of As, Cd, Cr, $\mathrm{Ni}$ and $\mathrm{Pb}$. As has the highest ECR followed by $\mathrm{Cd}$. Cr(VI) has high ECR than $\mathrm{Ni}$ and $\mathrm{Pb}$ even though its concentration in the $\mathrm{PM}$ is lowest and $\mathrm{Pb}$ has the highest, because of the much higher unit risk of $\mathrm{Cr}(\mathrm{VI})$, ranging from 7 to 50 times, compared to the unit risk of the Ni or Pb forms. The total ECRs based on the average values of As, Cd, Cr, $\mathrm{Ni}$ and $\mathrm{Pb}$ in $\mathrm{PM}_{2.5}$ is $4.34 \times 10^{-5}$. These results indicate that 4 or 5 people out of 100,000 could get cancer after exposure to the toxic trace metals in ambient $\mathrm{PM}_{2.5}$ residing or working near to a national highway.

\section{Conclusion}

The daily mean $\mathrm{PM}_{2.5}$ concentration at the sampling site has been observed as $286.23( \pm 41.1) \mu \mathrm{g} / \mathrm{m}^{3}$, which is three to four times higher as compared to the air quality standard for $\mathrm{PM}_{2.5}$. Concentrations have been found to be higher during night time as compared to daytime and during weekends than weekdays. The metal concentrations are in this trend: $\mathrm{Si}>\mathrm{K}>\mathrm{S}>\mathrm{Ca}=\mathrm{Fe}>\mathrm{Zn}=\mathrm{Pb}>\mathrm{Br}$. It is observed that $\mathrm{Si}$ has high co-relation with $\mathrm{Ca}$, Fe and $\mathrm{K}$, which may be due to crustal origin of all three elements; while $\mathrm{S}, \mathrm{Br}$ and $\mathrm{Pb}$ may be from vehicular exhaust emissions and/or abrasions due to brake and tyre wear. The potential health risks associated with different carcinogenic heavy metals have also been calculated. One of the health risk indicators, the excess cancer risk (ECR), is found to be in the order as $\mathrm{As}>\mathrm{Cd}>\mathrm{Pb}>\mathrm{Cr}>\mathrm{Ni}$. According to health risk assessment, 4 or 5 people out of 100,000 could get cancer after exposure to the toxic trace metals in ambient $\mathrm{PM}_{2.5}$ residing or working near to a national highway.

Table 1. ECR of PM-bound carcinogenic elements.

\begin{tabular}{|c|c|c|c|}
\hline Elements & $\mathrm{CA}, \mathrm{mg} / \mathrm{m}^{3}$ & IUR, $\left(\mathrm{mg} / \mathrm{m}^{3}\right)^{-1}$ & ECR \\
\hline As & $4.62 \mathrm{E}-03$ & $4.30 \mathrm{E}-03^{\mathrm{a}}$ & $1.99 \mathrm{E}-05$ \\
\hline $\mathrm{Cd}$ & $6.52 \mathrm{E}-03$ & $1.80 \mathrm{E}-03^{\mathrm{a}}$ & $1.17 \mathrm{E}-05$ \\
\hline $\mathrm{Cr}(\mathrm{VI})$ & $6.74 \mathrm{E}-04$ & $1.20 \mathrm{E}-02^{\mathrm{a}}$ & $8.09 \mathrm{E}-06$ \\
\hline $\mathrm{Ni}$ & $3.14 \mathrm{E}-03$ & $2.40 \mathrm{E}-04^{\mathrm{a}}$ & $7.55 \mathrm{E}-07$ \\
\hline $\mathrm{Pb}$ & $3.10 \mathrm{E}-01$ & $1.20 \mathrm{E}-05^{\mathrm{b}}$ & $2.95 \mathrm{E}-06$ \\
\hline Total ECR & & & $4.34 \mathrm{E}-05$ \\
\hline
\end{tabular}

${ }^{\mathrm{a}}$ Values taken from IRIS (Integrated Risk Information System). ${ }^{\mathrm{b}}$ Values taken from Cal EPA (California Environmental Protection Agency). 


\section{Acknowledgements}

The authors gratefully acknowledge the UKIERI, India for funding the project. The authors also acknowledge University Grant Commission (UGC), Government of India for providing fellowship to the student. The authors also thank CPCB, Delhi for providing necessary laboratory support. Ms. Megha Kanoje, M. Tech, Civil Engineering, IIT Delhi in collecting the samples is also highly acknowledged.

\section{References}

[1] Schwartz, J., Dockery, D.W. and Neas, L.M. (1996) Is Daily Mortality Associated Specifically with Fine Particles? Journal of Air and Waste Management Association, 46, 927-939. http://dx.doi.org/10.1080/10473289.1996.10467528

[2] Tsai, Y.I. and Chen, C. (2006) Atmospheric Aerosol Composition and Source Apportionments to Aerosol in Southern Taiwan. Atmospheric Environment, 40, 4751-4763. http://dx.doi.org/10.1016/j.atmosenv.2006.04.029

[3] Watson, J.G., Zhu, T., Chow, J.C., Engelbrecht, J., Fujita, E.M. and Wilson, W.E. (2002) Receptor Modeling Application Framework for Particle Source Apportionment. Chemosphere, 49, 1093-1136. http://dx.doi.org/10.1016/S0045-6535(02)00243-6

[4] Shah, M.H. and Shaheen, N. (2010) Seasonal Behaviours in Elemental Composition of Atmospheric Aerosols Collected in Islamabad, Pakistan. Atmospheric Research, 95, 210-223. http://dx.doi.org/10.1016/j.atmosres.2009.10.001

[5] Gulia, S., Nagendra, S.M.S., Khare, M. and Khanna, I. (2015) Urban Air Quality Management-A Review. Atmospheric Pollution Research, 6. http://dx.doi.org/10.5094/APR.2015.033

[6] Straif, K., Cohen, A. and Samet, J. (2013) Air Pollution and Cancer. International Agency for Research on Cancer, France.

[7] IARC (2013) Outdoor Air Pollution a Leading Environmental Cause of Cancer Deaths. http://www.iarc.fr/en/media-centre/iarcnews/pdf/pr221 E.pdf

[8] USEPA (1989) Risk Assessment Guidance for Superfund. http://www.epa.gov/oswer/riskassessment/ragsa/pdf/rags_a.pdf

[9] Park, E.J., Kim, D.S. and Park, K. (2008) Monitoring and Ambient Particles and Heavy Metals in a Residential Area of Seoul, Korea. Environmental Monitoring and Assessment, 137, 441-449. http://dx.doi.org/10.1007/s10661-007-9779-y

[10] Hieu, N.T. and Lee, B.K. (2010) Characteristics of Particulate Matter and Metals in the Ambient Air from a Residential Area in the Largest Industrial City in Korea. Atmospheric Research, 98, 526-537. http://dx.doi.org/10.1016/j.atmosres.2010.08.019

[11] USEPA (1998) Risk Assessment Guidance for Superfund: Volume I-Human Health Evaluation Manual (Part D). http://www.epa.gov/oswer/riskassessment/ragse/

[12] CPCB (2009) National Ambient Air Quality Standards. http://cpcb.nic.in/National_Ambient_Air_Quality_Standards.php

[13] USEPA (2011) National Ambient Air Quality Standards. http://www.epa.gov/air/criteria.html

[14] Khanna, I., Khare, M., Gargava, P., Jakhmola, B.K. and Mishra, N. (2014) Chemical Characterization of Fine Particulate Matter at a Kerbside of National Highway in Delhi, India. Proceedings of Better Air Quality Conference, Sri Lanka.

[15] Garg, B.D., Cadle, S.H., Mulawa, P.A., Groblicki, P.J., Laroo, C. and Parr, G.A. (2000) Brake-Wear Particulate Matter Emissions. Environmental Science and Technology, 34, 4463-4469. http://dx.doi.org/10.1021/es001108h

[16] Cadle, S., Mulawa, P., Hunsanger, E., Nelson, K., Ragazzi, R., Barrett, R., et al. (1999) Composition of Light Duty Motor Vehicle Exhaust Particulate Matter in the Denver, Colorado Area. Environmental Science and Technology, 33, 2328-2339. http://dx.doi.org/10.1021/es9810843

[17] Banerjee, A.D.K. (2003) Heavy Metal Levels and Solid Phase Speciation in Street Dusts of Delhi, India. Environmental Pollution, 123, 95-105. http://dx.doi.org/10.1016/S0269-7491(02)00337-8

[18] Luhana, L., Sokhi, R., Warner., L., Mao., H., Boulter., P., MeCrae., I., et al. (2004) Measurement of Non-Exhaust Particulate Matter. European Commission.

[19] Pant, P. and Roy, H. (2012) Estimation of the Contribution of Road Traffic Emissions to Particulate Matter Concentrations from Field Measurements: A Review. Atmospheric Environment, 77, 78-97. http://dx.doi.org/10.1016/j.atmosenv.2013.04.028

[20] Allen, J., Mayo, P., Hughes, L., Salmon, L. and Cass, G. (2001) Emissions of Size Segregated Aerosols from On-Road Vehicles in the Caldecott Tunnel. Environmental Science and Technology, 35, 4189-4197. http://dx.doi.org/10.1021/es0015545 
[21] Sternbeck, J., Sjodin, A. and Andreasson, K. (2002) Metal Emissions from Road Traffic and the Influence of Resuspension-Results from Two Tunnel Studies. Atmospheric Environment, 36, 4735-4744.

http://dx.doi.org/10.1016/S1352-2310(02)00561-7

[22] Karar, K., Gupta, A.K., Kumar, A. and Biswas, A.K. (2006) Characterization and Identification of the Sources of Chromium, Zinc, Lead, Cadmium, Nickel, Manganese, and Iron in PM10 at Two Sites of Kolkata, India. Environment Monitoring and Assessment, 120, 347-360. http://dx.doi.org/10.1007/s10661-005-9067-7

[23] IARC (2006) Inorganic and Organic Lead Compounds. Monograph on the Evaluation of Carcinogenic Risks to Humans. http://monographs.iarc.fr/ENG/Monographs/vol87/mono87.pdf

[24] IARC (2012) A Review of Human Carcinogens, Part C: Arsenic, Metals, Fibres, and Dusts, 100. Monographs on the Evaluation of Carcinogenic Risks to Humans. http://monographs.iarc.fr/ENG/Monographs/vol100C/mono100C.pdf

[25] USEPA (2004) Regional Screening Levels. http://www.epa.gov/region9/superfund/prg/ 